\title{
Innate Resistance and Phosphite Treatment Affect Both the Pathogen's and Host's Transcriptomes in the Tanoak-Phytophthora ramorum Pathosystem
}

\author{
Takao Kasuga ${ }^{1}{ }^{1}$, Katherine J. Hayden ${ }^{2,3}$, Catherine A. Eyre ${ }^{2}$, Peter J. P. Croucher ${ }^{2}$, Shannon Schechter ${ }^{2}$, \\ Jessica W. Wright ${ }^{4}$ and Matteo Garbelotto ${ }^{2, *}$ \\ 1 Crops Pathology and Genetics Research Unit, Agricultural Research Service, Davis, \\ United States Department of Agriculture, CA 95616, USA; tkasuga@ucdavis.edu \\ 2 Department of Environmental Science, Policy, \& Management, University of California, \\ Berkeley, CA 94720, USA; KHayden@rbge.org.uk (K.J.H.); catherine.eyre@gmail.com (C.A.E.); \\ pete@petercroucher.com (P.J.P.C.); sapphiresps@gmail.com (S.S.) \\ 3 Royal Botanic Garden, Edinburgh EH3 5NZ, UK \\ 4 United States Department of Agriculture, Forest Service, Pacific Southwest Research Station, \\ Davis, CA 95618, USA; jessica.w.wright@usda.gov \\ * Correspondence: matteog@berkeley.edu
}

check for updates

Citation: Kasuga, T.; Hayden, K.J.; Eyre, C.A.; Croucher, P.J.P.; Schechter, S.; Wright, J.W.; Garbelotto, M. Innate Resistance and Phosphite Treatment Affect Both the Pathogen's and Host's Transcriptomes in the Tanoak-Phytophthora ramorum Pathosystem. J. Fungi 2021, 7, 198. https://doi.org/10.3390/jof7030198

Academic Editor: Marco Thines

Received: 15 January 2021

Accepted: 6 March 2021

Published: 9 March 2021

Publisher's Note: MDPI stays neutral with regard to jurisdictional claims in published maps and institutional affiliations.

Copyright: (c) 2021 by the authors. Licensee MDPI, Basel, Switzerland. This article is an open access article distributed under the terms and conditions of the Creative Commons Attribution (CC BY) license (https:/ / creativecommons.org/licenses/by/ $4.0 /)$.

\begin{abstract}
Phosphites have been used to control Sudden Oak Death; however, their precise mode of action is not fully understood. To study the mechanism of action of phosphites, we conducted an inoculation experiment on two open-pollinated tanoak families, previously found to be partially resistant. Stems of treatment group individuals were sprayed with phosphite, and seven days later, distal leaves were inoculated with the Sudden Oak Death pathogen Phytophthora ramorum. Leaves from treated and untreated control plants were harvested before and seven days after inoculation, and transcriptomes of both host and pathogen were analyzed. We found that tanoak families differed in the presence of innate resistance (resistance displayed by untreated tanoak) and in the response to phosphite treatment. A set of expressed genes associated with innate resistance was found to overlap with an expressed gene set for phosphite-induced resistance. This observation may indicate that phosphite treatment increases the resistance of susceptible host plants. In addition, genes of the pathogen involved in detoxification were upregulated in phosphite-treated plants compared to phosphite-untreated plants. In summary, our RNA-Seq analysis supports a two-fold mode of action of phosphites, including a direct toxic effect on P. ramorum and an indirect enhancement of resistance in the tanoak host.
\end{abstract}

Keywords: phosphonate; Notholithocarpus densiflorus; Sudden Oak Death (SOD); in planta RNA-Seq; plant defense; gene set enrichment analysis (GSEA)

\section{Introduction}

Phosphites, salts or esters of phosphonic acid, are systemic compounds first shown to be highly effective against diseases caused by oomycetes in the 1970s (reviewed in [1]) and have since been used widely as fungicides in horticulture and natural ecosystems [2,3]. Nonetheless, the precise mode of action of these compounds is not fully understood. It has been postulated that phosphite compounds may have both direct and indirect effects on the oomycete Phytophthora spp. At high doses, they act directly on pathogen growth and sporulation [4-6], while at low doses they stimulate host defenses, including an increase in plant defensive enzymes [4,5,7-9]. Phosphite's stimulation of extant host defenses has been hypothesized to be the reason for the compounds' varying actions among individuals $[7,10,11]$.

First recognized in the mid 1990s [12,13], the invasive pathogen Phytophthora ramorum has rapidly spread among coastal forests of California and Oregon, killing tens of millions 
of trees. Tanoaks are among the most susceptible wild North American hosts to the pathogen, and experience both the deadly but rarely infectious bole form of the disease this pathogen causes (the widely known "Sudden Oak Death"), and the foliar and infectious form of the disease known as "Ramorum Blight" [14]. Tanoak has experienced the highest mortality rates among wild hosts [15-17], to the point that it is widely speculated that extinction of local populations may soon occur in heavily infested areas [18,19]. Agri-fos (Agrichem, potassium phosphite salts) is a registered fungicide in California and is now used for the protection of trees from Sudden Oak Death (causal organism the oomycete Phytophthora ramorum) in wildlands and particularly for the protection of oaks (Quercus spp.) and tanoaks (Fagaceae: Notholithocarpus densiflorus (Hook. and Arn.) Manos, Cannon and S. Oh) $[13,20,21]$.

While the ecological and cultural importance of tanoaks is well established [22], owing primarily to their low commercial value, tanoaks have not been widely propagated for forestry. There are no extant plantations of tanoaks with a known multigenerational pedigree, limiting the scope of study of disease resistance traits using traditional quantitative genetic techniques. For example, the development of quantitative trait loci from phenotypic observation and known family relationships is impossible. Since the onset of the Sudden Oak Death epidemic in California and Oregon, the potential utility of known breeding stocks for the study of the genetics of pathogen resistance and other phenotypic traits has been recognized, and a USDA-Forest Service-Pacific Southwest Research Station-funded common garden study of open-pollinated seed has been established in Berkeley, CA [20,23]. The common garden research has resulted in the identification of maternal family groups with signs of disease resistance, including some with markedly lower infection rates. Note that the use of "resistance" and "tolerance" is nonstandard in plant pathology. In this paper, resistance refers to the presence of host mechanisms that either limit the establishment of infection or limit the spread of an infection within a host, sensu Roy and Kirchner [24]. Combining these two phenotypes, i.e., reduced disease incidence and reduced disease severity, in the same category of "disease resistance" makes sense for the tanoak-P. ramorum pathosystem, given our previous results showing that tanoak families displaying reduced disease severity in the laboratory had a higher rate of survival in field trials, due to reduced disease incidence [20]. Despite the absence of commercial forestry sources of germplasm, there are considerable genomic resources available in this pathosystem. Notably, there are both a P. ramorum genome sequence [25], and a de novo assembled transcriptome (a reconstructed transcriptome from RNA-Seq experiments) of tanoak [26].

Another complication of the tanoak-P. ramorum pathosystem is the lack of established clonal propagation, preventing replication using identical genotypes, combined with the presence of quarantine regulations that require the destruction of any inoculated plants. Thus, it is currently impossible to know whether individual trees will demonstrate resistant or susceptible reactions prior to inoculation. To overcome this barrier, we used previously identified open-pollinated family groups which carried resistance, that is in which approximately $20 \%$ of offspring demonstrated a resistant phenotype (dieback $25 \%$ or less) [20]. Hereafter, the resistance phenotype of phosphite-untreated tanoak is defined as "innate resistance" to distinguish it from phosphite-induced resistance.

Here we examine gene expression in seedlings exposed to P. ramorum, both with and without the application of phosphonate. We hypothesized that phenotypic differences on the outcome of infection correlate with differences in regulation of key genes before as well as after the infection takes place. Hence, comparisons among transcriptomes may lend insights into the genes involved in innate tanoak resistance and into the mode of action of phosphites. In addition, in plant pathology research, disease phenotypes are monitored in detail; however, actual biomass of pathogens, their physiological states in planta, and gene regulation have been less studied due to the difficulty of in planta observation. Taking advantage of deep sequencing technology, we have also investigated gene activity of the pathogen in inoculated tanoaks. We hypothesized that phosphite in the plant tissue 
perturbs the transcriptome of $P$. ramorum in planta and changes in gene activity would help to elucidate the mode of action of phosphites.

\section{Materials and Methods}

\subsection{Experiment Overview}

We chose two open-pollinated tanoak half-sibling family groups (Family 10 and 12) that carried innate resistance, i.e., families that were previously tested and had shown innate resistance to P. ramorum [20]. Multiple inoculations were performed on previously unchallenged members of the two families, with leaves harvested and flash-frozen for RNA extraction before and one week after inoculation. The remaining inoculated leaves were left intact, and the trees were followed over the course of five weeks to determine disease phenotype. The design and the phenotypic results allowed us to study gene expression during disease response in phosphite-treated resistant hosts (in which the treatment worked as expected), in phosphite-treated but susceptible hosts (in which phosphite was not effective nor was there innate resistance), and in untreated naturally susceptible or resistant trees.

\subsection{Experimental Design for Gene Expression Analysis}

Tanoaks for inoculation were selected from a container garden located in Berkeley, California, housed outdoors under $50 \%$ shade. Seedlings had been grown from seed in $6.9 \mathrm{~cm} \times 25.4 \mathrm{~cm}$ cones, and at one year of age potted up to $10.2 \mathrm{~cm} \times 10.2 \mathrm{~cm} \times 30.5 \mathrm{~cm}$ pots, all in UC mix growing medium [27]. A total of 272 seedlings from 34 open pollinated families in three California regions were prescreened using inoculation experiments. Two families (10 and 12) were selected on the grounds of prior observation of disease resistance levels up to $25 \%$ per family, based on the intact stem inoculation method described in [20]. For each open-pollinated sampling family, 4-year old seedlings were randomly assigned to treatments ( $\mathrm{P}$, phosphite) or control ( $\mathrm{C}$, no phosphite) groups (Figure 1). Within each treatment group, individuals were randomly assigned to be inoculated with a P. ramorum zoospore suspension or to the non-inoculated control. There was one non-inoculated control per family and treatment.
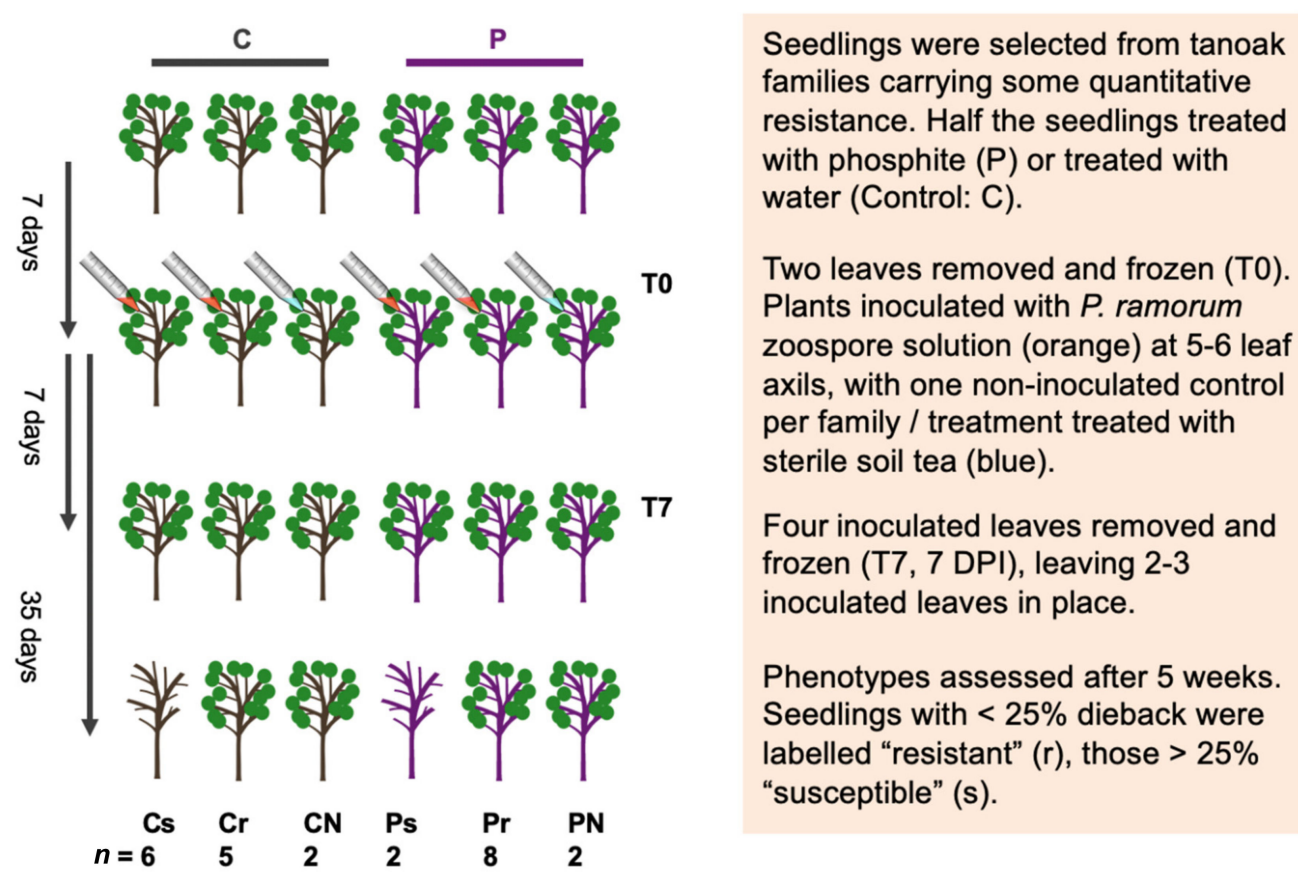
families carrying some quantitative resistance. Half the seedlings treated with phosphite $(P)$ or treated with water (Control: C).

Two leaves removed and frozen (T0). Plants inoculated with $P$. ramorum zoospore solution (orange) at 5-6 leaf axils, with one non-inoculated control per family / treatment treated with sterile soil tea (blue).

Four inoculated leaves removed and frozen (T7, $7 \mathrm{DPI}$ ), leaving 2-3 inoculated leaves in place.

Phenotypes assessed after 5 weeks. Seedlings with $<25 \%$ dieback were labelled "resistant" (r), those > $25 \%$ "susceptible" (s).

Figure 1. Experimental design. A total of 25 plants across 2 families were subjected to the experiment. Abbreviations are C: water control, P: phosphite treated, T0: time 0, T7: 7 days post inoculation, Cs: water control susceptible, Cr: water control resistant, CN: water control uninoculated, Ps: phosphite-treated susceptible, Pr: phosphite-treated resistant, PN: phosphite-treated uninoculated. Sample size $(n)$ is indicated for each treatment group. 


\subsection{Phosphite Treatment}

We have previously shown that bark application of phosphites was ineffective whereas bark applications of phosphites with the organosilicate surfactant Pentra-bark ${ }^{\mathrm{TM}}$ (Agrichem, Medina, OH, USA) were consistently effective in suppressing colonization by P. ramorum without causing observable phytotoxicity [28]. Plants were treated with a $2.4 \mathrm{M}$ potassium phosphite solution (48.75\% v/v Agri-Fos, Agrichem, Medina, OH, USA) mixed with a $2.5 \%$ surfactant (Pentra-Bark, Agrichem Manufacturing Industries) seven days prior to inoculation. Hereafter, "phosphite treatment" refers to the treatment with phosphite and the surfactant solution. The treatment was applied by hand ensuring coverage of $10 \mathrm{~cm}$ of each stem upwards from the soil line, with care taken to avoid application directly to leaves. Control plants were sprayed with deionized $\mathrm{H}_{2} \mathrm{O}$.

\subsection{Inoculum and Leaf Harvest}

P. ramorum isolate MK1461, first isolated from a California bay in San Mateo County, California, belonging to the NA1 lineage, was found previously to be of intermediate but consistent aggressiveness, and was used for all tanoak inoculations. To prepare zoospores for inoculation, cultures were grown on $10 \% v / v$ clarified V8 agar [29] for 14 days at $18{ }^{\circ} \mathrm{C}$. To induce sporangial formation, cultures were cut into squares approximately $1 \mathrm{~cm}^{2}$, and placed into empty petri plates. Plates were flooded with a sterile $1 \% w / v$ soil extract solution (soil tea) and incubated in the dark at $18{ }^{\circ} \mathrm{C}$ for $48 \mathrm{~h}$, until sporangia were formed. Zoospore release from sporangia was induced by cold shocking the cultures as follows. The mycelial squares incubated in multiple petri plates were consolidated into a single vessel before being placed in ice water for $30 \mathrm{~min}$. After that, the mycelial squares were further incubated at room temperature for one hour. Zoospores were quantified using a hemocytometer, and diluted with sterile soil tea to a final concentration of $5 \times 10^{4}$ zoospores per $\mathrm{mL}$. This zoospore suspension was used immediately for seedling inoculations.

After the phosphite treatments, all seedlings were transferred to growth chambers with a 16-h light ( 6 a.m. to 10 p.m.): 8 -h dark cycle at $18{ }^{\circ} \mathrm{C}$, and watered every 2 days with supplemental regular misting to maintain humidity. At seven days after phosphite treatment, two leaves were removed and flash-frozen in liquid nitrogen (T0) and stored at $-80^{\circ} \mathrm{C}$. Each seedling was then lightly wounded with a scalpel and inoculated at leaf axils. Then, $100 \mu \mathrm{L}$ of zoospore suspension was applied to the leaf axil and held in place by a small wax cup (Parafilm M, Bemis Company, Neenah, WI, USA) formed at the base. One seedling per each family and treatment was randomly selected for a mock inoculation with sterile soil tea as a negative control. The number of leaf axils was determined by seedling architecture: where 6 distinct leaves (not part of the same whorl) capable of holding inoculum in this way were identified, 5 were inoculated. One non-inoculated control had only 4 "inoculation" points. At seven days post-inoculation (T7), 4 inoculated leaves per tree were collected, flash-frozen in liquid nitrogen, and stored at $-80^{\circ} \mathrm{C}$. In order to minimize diurnal variation of the transcriptome, all leaves were harvested between $1 \mathrm{pm}$ and $4 \mathrm{pm}$. Trees were maintained under the same conditions for five weeks postinoculation. After five weeks (T35), seedlings were assessed for dieback using a scale $0-4$ based on quartiles of percentage of dead above-ground tissue: $0=$ no dieback, $1=1-25 \%$, $2=26-50 \%, 3=51-75 \%, 4=76-100 \%$.

\subsection{RNA Extraction}

Leaves were subsampled while frozen by excising small sections from the inoculation point around the midrib at the base of each leaf, approximately encompassing the area exposed to inoculum. Samples were ground to powder while frozen in Lysing Matrix A tubes (MP Biomedicals, Irvine, CA, USA), with an additional ceramic bead in each tube, using an MP Biosystems FastPrep with CryoPrep ${ }^{\mathrm{TM}}$ attachment. RNA was extracted using a CTAB-Chloroform-Isoamyl alcohol extraction and lithium chloride precipitation [30,31]. Following precipitation, pellets were air dried and subjected to a further clean-up using a ZR RNA MiniPrep ${ }^{\mathrm{TM}}$ (Zymo Research, Irvine, CA, USA), including an on-column DNase 
treatment. Total RNA integrity was assessed using an Agilent 2100 Bioanalyzer (Agilent Technologies, Santa Clara, CA, USA). Although tanoak samples were pulverized on dry ice, which was followed by a CTAB extraction protocol, RNA Integrity Numbers (RINs) evaluated by Agilent bioanalyzer were often low (median 4.7). Unlike mammalian samples, plant cells have chloroplast ribosomes and a variable ribosomal RNA size, which can lower the RNA RIN value even when purified RNA is intact [32]. In addition, samples with necrotic tissues were expected to contain some degraded RNA from the host as well as the pathogen. We hence proceed to RNA-Seq cDNA library construction regardless of the RIN value and RNA-Seq was carried out. Integrity of RNA was then bioinformatically evaluated and samples with degraded RNA were removed from the dataset (see the next section).

\subsection{Tanoak RNA-Seq cDNA Library Construction}

A total of 46 plant samples were used for library construction. Sufficiently high quantity of RNA (yield above $0.1 \mu \mathrm{g}$ ) was extracted from 44 of 46 samples of the combined tanoak and P. ramorum tissue, as described above and was used to prepare RNA-Seq libraries using Illumina TruSeq v2 (Illumina, San Diego, CA, USA). Twelve samples per lane were indexed, multiplexed, and sequenced on a HiSeq2000 as $100 \mathrm{bp}$ paired-end runs at QB3 Genomics Sequencing Laboratory at UC Berkeley. Transcript Integrity Numbers (TINs) were then calculated using RSeQC package version 2.6.4 [33] after RNA-Seq reads were aligned to the tanoak de novo transcriptome assembly [26] with align function in the Rsubread package [34], which was run on R 3.3.3 statistical software [35]. TIN values range from 0 (the most degraded) to 100 (the most intact). As median TIN scores of most samples were high (median 80.3), we judged that mRNA integrity of most transcripts were sufficiently high for reliable RNA-Seq analysis (Supplementary Table S1).

\subsection{Bioinformatics Pipeline}

\subsubsection{Tanoak Expression}

By first aligning sequences to the $P$. ramorum transcriptome, we were able to subtract both Phytophthora and highly conserved sequences, leaving only tanoak transcripts. Briefly, the "view" function in SAMtools version 1.9 [36] with options -u -f 12 -F 256 was used to subtract $P$. ramorum transcripts from the RNA sequence files mapped to the $P$. ramorum assembly in the BAM format. Resulting BAM files were subsequently converted to fastq file format using the "bam2fq" function in SAMtools.

The genome sequence of tanoak is not yet available and the gene set represented in the de novo transcriptome of tanoak [26] is likely incomplete. The genome of English oak Quercus robur, the most closely related species whose genome has been sequenced, was used as a reference genome. Gene Ontology (GO) terms [37,38] and Kyoto Encyclopedia of Genes and Genomes (KEGG) pathways [39], implemented in Blast2GO [40] were used to annotate the English oak genome (Table S2). The tanoak-only RNA sequences were aligned to the English oak assembly Qrob_PM1N.fa.gz (https: / / urgi.versailles.inra.fr/download/ oak/Qrob_PM1N.fa.gz, accessed on 8 March 2021) [41] with the align function in the Rsubread package [34]. The mapped reads were then counted using the featureCounts function in the Rsubread package with a gene coordinate file in SAF format derived from an English oak gene model coordinate file, Qrob_PM1N_genes_20161004.gff. The Pearson's correlation coefficient between global mRNA expression patterns was used to cluster tanoak transcriptomes using the hclust function [42] with the average linkage option in R 3.3.3 statistical software. DESeq2 [43] was used for expression quantification between transcriptome clusters and treatments. The default values of the parameters and workflows outlined in software documentation were used. A total of four comparisons were analyzed for differential expression.

\subsubsection{P. ramorum Expression}

RNA sequences were aligned to the $P$. ramorum assembly ramorum1.allmasked (https://genome.jgi.doe.gov/portal/Phyra1_1/Phyra1_1.download.ftp.html, accessed on 
8 March 2021) [25] with align function in the Rsubread package [34]. The mapped reads were then counted across the P. ramorum genes using the featureCounts function in the Rsubread package with a gene coordinate file in SAF format derived from a P. ramorum gene model coordinate file, FM_Phyra1_1.gtf. Uninfected tanoak transcriptomes were also mapped to the P. ramorum genome and sixteen $P$. ramorum genes to which tanoak transcripts were mapped were removed from the dataset. The remaining transcripts were used for further analysis. Differentially expressed genes between groups were estimated using DESeq2 [43] with the un-normalized gene count dataset from featureCounts. A false discovery rate cut off $<0.05$ was used to filter differentially expressed genes. P. ramorum gene models (ramorum1.proteins.fasta in https://genome.jgi.doe.gov/portal/Phyra1_1/Phyra1 _1.download.ftp.html, accessed on 8 March 2021) were annotated with gene ontology (GO) terms [37,38] and KEGG pathways [39] as implemented in Blast2GO [40].

For the P. ramorum and tanoak datasets, a gene set enrichment analysis (GSEA) [44] was used to evaluate over- or under-representation of functional categories (GO, or KEGG pathway) across expression gene clusters or differentially expressed gene sets using Fisher's exact test function fisher.test() with the statistical software R 3.3.3 or a same function implemented in Blast2GO. The false discovery rate according to Benjamini and Hochberg [45] was used for multiple hypothesis correction (adjusted $p$-value $<0.05$ ).

\subsubsection{Availability of Data and Material}

BAM files for the original Illumina RNA sequencing data aligned to the de novo tanoak transcriptome library and the same data aligned to $P$. ramorum reference genome were deposited in the NCBI Sequence Read Archive under study accessions SRP157197 and SRP157863, respectively.

\section{Results}

\subsection{Tanoak Families Differed in the Presence of Innate Resistance and in the Effectiveness of Phosphite Treatment}

Two maternal families of tanoak, previously characterized as having $12.5-25 \%$ of their offspring resistant to zoospore inoculation by P. ramorum isolate MK1461, were examined for disease resistance and phosphite response (Figure 1) (see Methods for details). Leaves of phosphite-treated and control seedlings were sampled prior to inoculation (T0 samples) and seven days post inoculation (T7 samples). Our previous work has showed that efficacy of the systemic fungicide is consistently seen seven days post treatment [46]. At T7, foliar lesions were seen in many inoculated leaves, whereas foliage dieback symptoms were not yet seen. Tanoak seedlings challenged with $P$. ramorum revealed a range of responsiveness to phosphite treatment (Figure 2). Family 10 was the most resistant in the absence of phosphite, with 5 out of 9 seedlings having mild or zero dieback following inoculation. Notably, Family 12 had a greater frequency of dieback (6/8) without treatment, but 0 of 8 phosphite-treated seedlings showed severe dieback symptoms.

A total of 44 RNA samples were sequenced and transcript integrity number (TIN) was estimated for each sample to measure the level of RNA integrity (Supplementary S1). It was found that median TIN scores, which correlate well with RNA integrity number (RIN), were sufficiently high (above 75 ) for 34 of the 44 samples. All but one sample showing TIN scores below 75 were removed from the dataset. The only sample having a low TIN score $(49.5 \%)$ was a T7 sample, which showed the highest percentage of $P$. ramorum reads $(13.9 \%)$ and was used only for hierarchical clustering and in planta transcriptome analysis of the pathogen. 


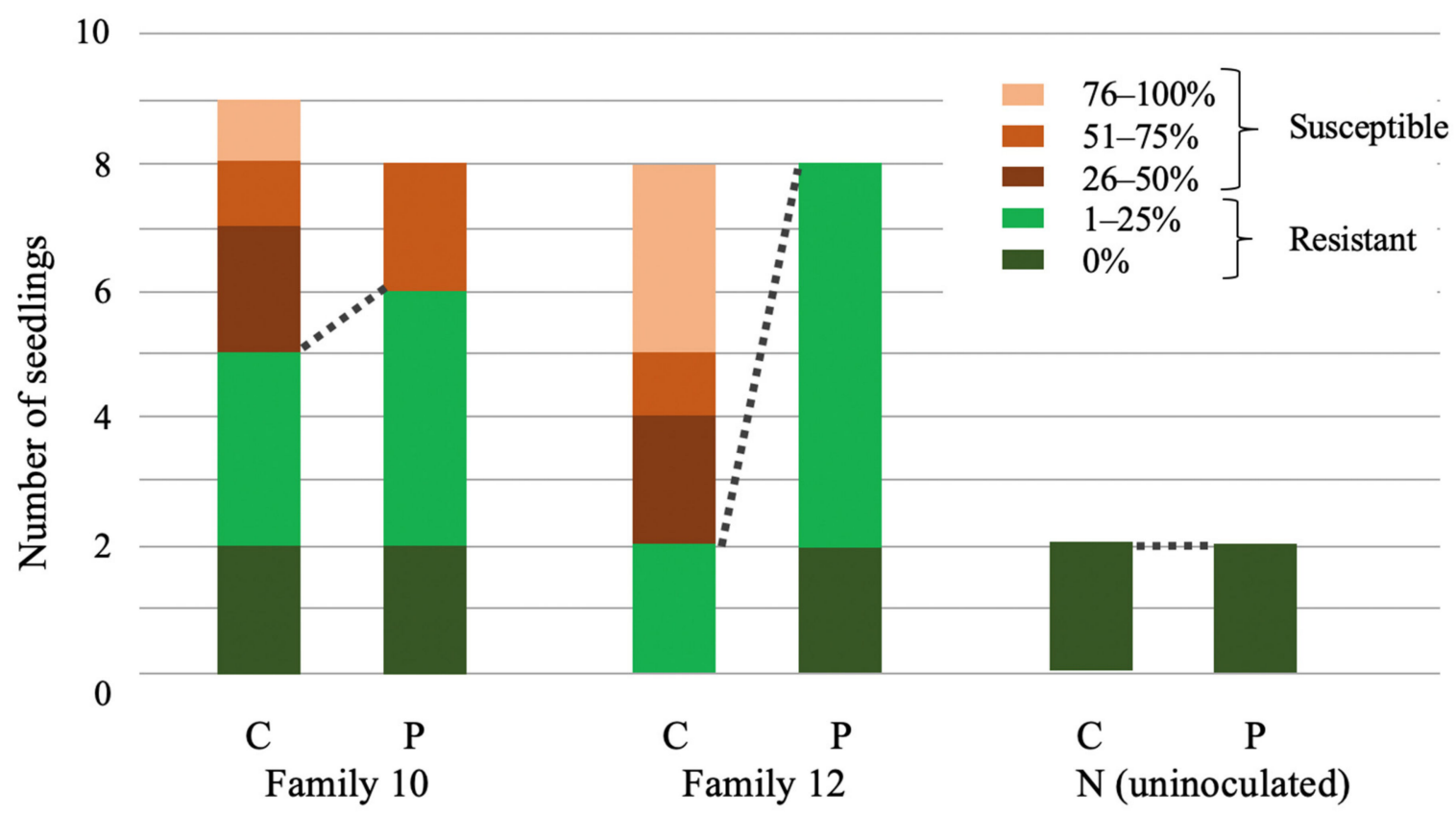

Figure 2. Effect of phosphite on reduction of tanoak dieback five weeks post inoculation. The y-axis shows the number of individual plants treated with either water (C) or phosphite (P) for each family. Dieback 0-25\% is defined as resistant, and $26-100 \%$ susceptible. Samples with dieback between $26-50 \%$ were excluded from RNA-Seq analysis. None of the four uninoculated plants $(\mathrm{N})$, treated with water or phosphite, showed disease symptoms. Dotted lines join portions of seedlings that showed resistance.

\subsection{Clustering of Expression Revealed Factors Influencing Tanoak Transcriptomes}

Of the 35 transcriptomes, 15 were from samples at T0 (seven days after phosphite treatment, just before inoculation), and 20 were from samples at T7 (seven days after inoculation). After the subtraction of P. ramorum transcripts, the 35 tanoak transcriptomes were mapped to the English oak genome and were hierarchically clustered according to their global expression patterns (Figures 3 and 4).

Hierarchical clustering analysis showed three distinctive clusters. Cluster A and cluster B contained only samples collected at T7 and never included uninoculated controls (marked with " $\mathrm{N}$ "). Cluster A contained primarily T7 samples with susceptible phenotypes (Fisher's exact test $p=0.031$, Document S1). In comparison to Cluster A and B, Cluster C contained relatively homogenous transcriptomes comprising all the T0 samples (resistant or susceptible, Figure $4 \mathrm{a}$ ) and a part of T7 samples with a predominance of resistant phenotypes (dieback $0-25 \%$ ). Transcriptomes of all non-inoculated controls at $\mathrm{T} 0$ and T7 were also found in Cluster C. Cluster C contained primarily uninfected samples (all T0 samples and non-inoculated T7 samples, Fisher's exact test, $p<0.001$, Document S1). In summary, the hierarchical clustering of tanoak transcriptomes was associated with disease symptoms and infection status. The effect of phosphite treatment was not readily recognizable.

Of the total of 25,808 predicted genes in the English oak genome, 14,964 genes (58\%) found highly similar sequences in the tanoak de novo transcriptome assembly at DNA sequence identity of $70 \%$ or larger. Differentially expressed genes (DEGs) between clusters were then analyzed in pairwise comparisons. Between clusters (B and C) and Clusters (A and C), 11,102 and 13,641 DEGs were identified respectively, of which 8460 genes were overlapping with the same directions of fold changes. Because a large portion overlaps, transcriptomes in Cluster A and B were combined, and DEGs between the combined transcriptomes (cluster AB) and cluster $C$ were analyzed. As a result, 13,443 DEGs were identified, of which 11,502 genes (86\%) overlapped with DEGs in the clusters A and C 
comparison. 7178 and 6265 genes were upregulated and downregulated in the cluster $A B$ (Table 1, Table S3).

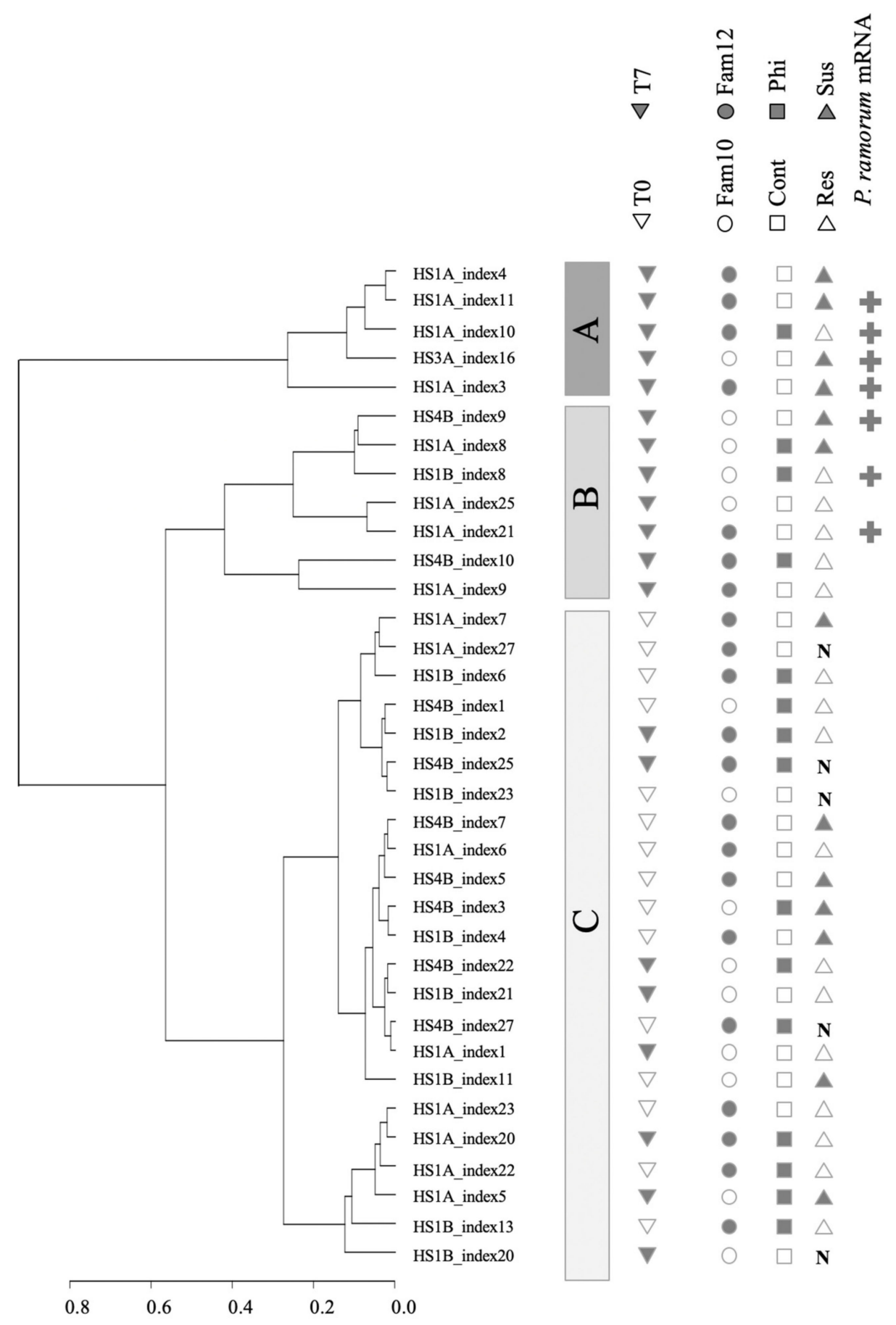

Figure 3. Hierarchical clustering of 35 tanoak transcriptomes showing three distinctive clusters A, B, and C. Sampling time (T0 or T7), tanoak family (Family 10 or 12), phosphite treatment (Phi: phosphite-treated and Cont: water control), disease phenotypes at 35 DPI (Res: resistant or Sus: susceptible), as well as occurrence of $P$. ramorum mRNA are indicated. $\mathrm{N}$ indicates non-inoculation control. Labels on terminal branches indicate IDs for cDNA libraries. 


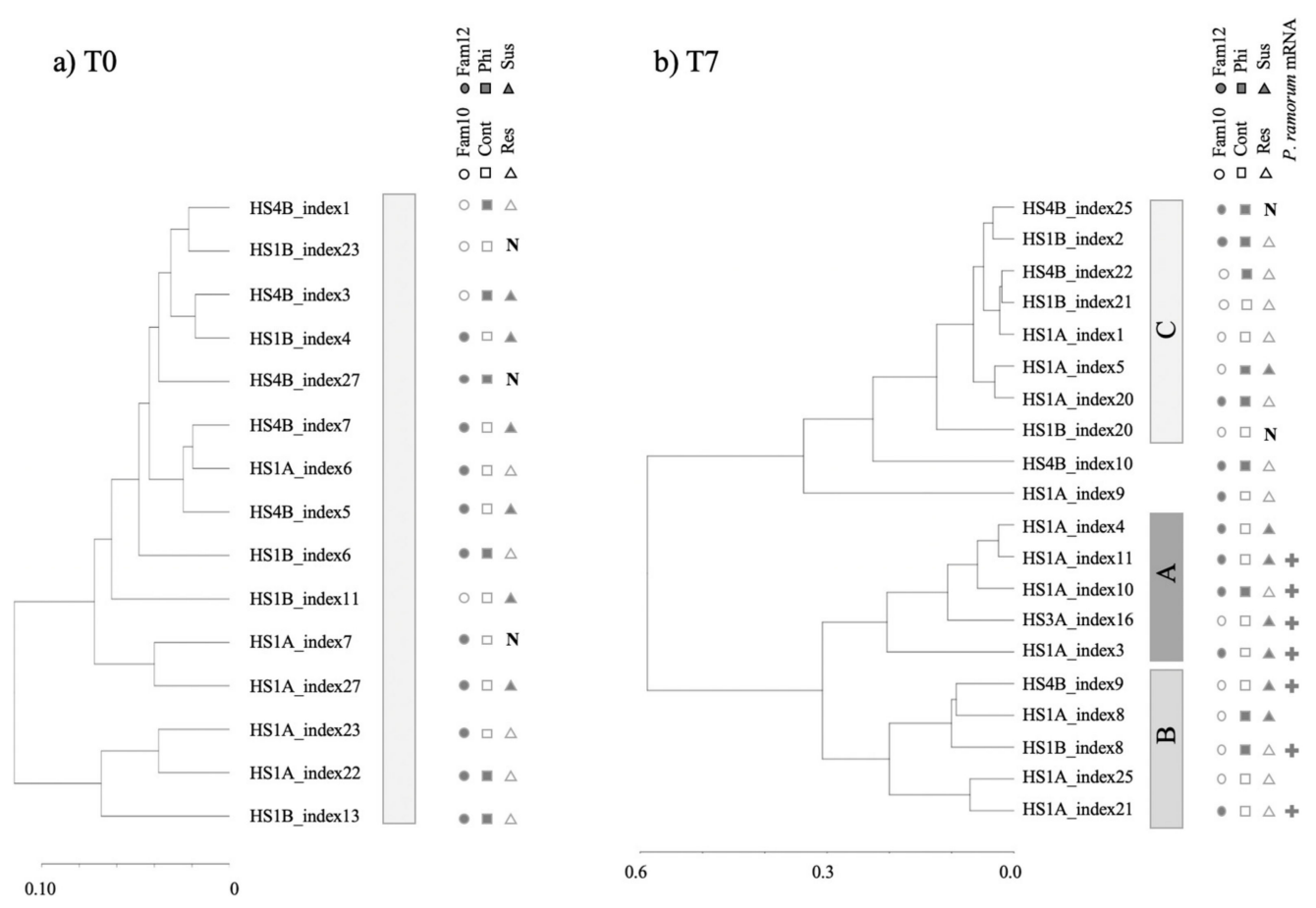

Figure 4. Hierarchical clustering of (a) 15 tanoak transcriptomes sampled at T0 and (b) 20 tanoak transcriptomes sampled at T7. Three clusters A, B, and C were defined in Figure 3. Tanoak family (Family 10 or 12), phosphite treatment (Phi: phosphite-treated and Cont: water control), disease phenotypes at 35 DPI (Res: resistant or Sus: susceptible), as well as occurrence of $P$. ramorum mRNA are indicated. $\mathrm{N}$ indicates non-inoculation control.

Table 1. Summary of deferentially expressed genes and enriched GO terms in group comparisons.

\begin{tabular}{|c|c|c|c|c|c|c|}
\hline Comparison & Family & ${\mathrm{N} v \mathrm{~N}^{1}}^{1}$ & $D E U^{2}$ & GO and $\mathrm{KEGG}^{3}$ & DE Down $^{2}$ & $\mathrm{GO}^{3}$ \\
\hline & & & \multicolumn{2}{|c|}{$\mathrm{AB}$ up } & \multicolumn{2}{|c|}{$\mathrm{AB}$ down } \\
\hline \multirow[t]{2}{*}{$\mathrm{AB}$ and $\mathrm{C}$ clusters } & F10 \& F12 & 12 v 23 & 7178 & 226,40 & 6265 & 143,8 \\
\hline & & & \multicolumn{2}{|c|}{ Cr up } & \multicolumn{2}{|c|}{ Cr down } \\
\hline \multirow[t]{2}{*}{$\mathrm{Cr}$ and $\mathrm{Cs}$ plants at $\mathrm{T} 0$} & F12 & $4 \vee 2$ & 268 & 104,4 & 198 & 6,1 \\
\hline & & & \multicolumn{2}{|c|}{ P up } & \multicolumn{2}{|c|}{ P down } \\
\hline \multirow[t]{2}{*}{$\mathrm{P}$ and $\mathrm{C}$ plants at T0 } & F12 & $6 \times 3$ & 0 & 0,0 & 0 & 0,0 \\
\hline & & & \multicolumn{2}{|c|}{ Pr up } & \multicolumn{2}{|c|}{ Pr down } \\
\hline Pr and Cs plants at T0 & F12 & $4 \mathrm{v} 3$ & 31 & 2,0 & 16 & 0,0 \\
\hline
\end{tabular}

${ }^{1}$ Numbers of seedlings used in the comparison; ${ }^{2}$ Numbers of upregulated and downregulated deferentially expressed (DE) genes are shown (adjusted $p<0.05$ ); ${ }^{3}$ Number of enriched Gene Ontology (GO) Biological Process and Kyoto Encyclopedia of Genes and Genomes (KEGG) Pathways (adjusted $p<0.05$ ); Abbreviations: $\mathrm{C}$ water control, $\mathrm{P}$ phosphite treated, T0 time 0, Cr water control resistant, Cs water control susceptible, Pr phosphite-treated resistant.

A gene set enrichment analysis (GSEA) was then employed to elucidate physiological differences between clusters $\mathrm{AB}$ and $\mathrm{C}$ observed in transcripts mapped to the English oak genome. GSEA on KEGG pathways indicated upregulation of genes involved in phenylpropanoid biosynthesis and phenylalanine metabolism, which include two genes encoding for phenylalanine ammonia-lyases (PAL), enzymes involved in the first step of the biosynthesis of several phytoalexins and lignin [47]. On the other hand, genes involved in photosynthesis, starch and sucrose biosynthesis were downregulated in cluster $\mathrm{AB}$ (i.e., upregulated in cluster C, Table 2). GSEA on GO terms was partly overlapping GSEA on KEGG pathways, highlighting upregulation of genes involved in defense (high in $A B$ ) and downregulation of those in photosynthesis. It is noteworthy that defense-related GO terms such as jasmonic acid metabolic process, and chitin catabolic process were enriched 
in cluster $\mathrm{AB}$. In addition, the GO enrichment analysis indicated upregulation of genes for respiration and energy generation in cluster AB. Downregulation of photosynthesis genes and upregulation of genes for energy generation are hallmarks of plant immune processes [48-50]. In conclusion, GSEA showed that transcriptomes in cluster AB represent infection and plant defense whereas those in cluster $C$ represent free of infection or disease with minor symptoms. The DEGs and results of GSEA are shown in Table S3 and Table 2, respectively.

Table 2. GO and KEGG pathway enrichment analysis on tanoak transcriptomes.

\begin{tabular}{|c|c|c|c|}
\hline GO and KEGG ID ${ }^{1}$ & Cluster $^{2}$ & Description & False Discovery Rate ${ }^{3}$ \\
\hline map01130 & AB_up & Biosynthesis of antibiotics & $7.76 \times 10^{-17}$ \\
\hline map00980 & AB_up & Metabolism of xenobiotics by cytochrome P450 & $2.57 \times 10^{-11}$ \\
\hline map00010 & AB_up & Glycolysis/Gluconeogenesis & $2.57 \times 10^{-9}$ \\
\hline map00982 & AB_up & Drug metabolism-cytochrome P450 & $2.88 \times 10^{-9}$ \\
\hline map00480 & AB_up & Glutathione metabolism & $4.26 \times 10^{-9}$ \\
\hline map00983 & AB_up & Drug metabolism-other enzymes & $6.02 \times 10^{-9}$ \\
\hline map00520 & AB_up & Amino sugar and nucleotide sugar metabolism & $6.93 \times 10^{-9}$ \\
\hline map04660 & AB_up & $\mathrm{T}$ cell receptor signaling pathway & $1.46 \times 10^{-6}$ \\
\hline map00020 & AB_up & Citrate cycle (TCA cycle) & $1.56 \times 10^{-6}$ \\
\hline map04658 & AB_up & Th1 and Th2 cell differentiation & $1.81 \times 10^{-5}$ \\
\hline map00400 & AB_up & Phenylalanine, tyrosine and tryptophan biosynthesis & $6.29 \times 10^{-5}$ \\
\hline map00230 & AB_up & Purine metabolism & $6.48 \times 10^{-5}$ \\
\hline map00940 & AB_up & Phenylpropanoid biosynthesis & $6.63 \times 10^{-5}$ \\
\hline map00730 & AB_up & Thiamine metabolism & $7.04 \times 10^{-5}$ \\
\hline map00830 & AB_up & Retinol metabolism & $7.92 \times 10^{-5}$ \\
\hline map00720 & AB_up & Carbon fixation pathways in prokaryotes & $1.80 \times 10^{-4}$ \\
\hline map00071 & AB_up & Fatty acid degradation & $2.50 \times 10^{-4}$ \\
\hline map00592 & AB_up & alpha-Linolenic acid metabolism & $2.89 \times 10^{-4}$ \\
\hline map00625 & AB_up & Chloroalkane and chloroalkene degradation & $1.29 \times 10^{-3}$ \\
\hline map00620 & AB_up & Pyruvate metabolism & $1.30 \times 10^{-3}$ \\
\hline map00680 & AB_up & Methane metabolism & $1.37 \times 10^{-3}$ \\
\hline map00640 & AB_up & Propanoate metabolism & $1.41 \times 10^{-3}$ \\
\hline map00760 & AB_up & Nicotinate and nicotinamide metabolism & $2.01 \times 10^{-3}$ \\
\hline map00626 & AB_up & Naphthalene degradation & $2.58 \times 10^{-3}$ \\
\hline map00260 & AB_up & Glycine, serine and threonine metabolism & $3.12 \times 10^{-3}$ \\
\hline map00270 & AB_up & Cysteine and methionine metabolism & $3.48 \times 10^{-3}$ \\
\hline map00040 & AB_up & Pentose and glucuronate interconversions & $6.21 \times 10^{-3}$ \\
\hline map00350 & AB_up & Tyrosine metabolism & $6.84 \times 10^{-3}$ \\
\hline map00051 & AB_up & Fructose and mannose metabolism & $9.69 \times 10^{-3}$ \\
\hline GO:0016567 & AB_up & protein ubiquitination & $4.16 \times 10^{-9}$ \\
\hline GO:0010951 & AB_up & negative regulation of endopeptidase activity & $5.62 \times 10^{-8}$ \\
\hline GO:0006888 & AB_up & $\begin{array}{l}\text { endoplasmic reticulum to Golgi } \\
\text { vesicle-mediated transport }\end{array}$ & $1.02 \times 10^{-4}$ \\
\hline GO:0006749 & AB_up & glutathione metabolic process & $1.68 \times 10^{-4}$ \\
\hline GO:0006032 & AB_up & chitin catabolic process & $3.14 \times 10^{-4}$ \\
\hline GO:0032482 & AB_up & Rab protein signal transduction & $3.14 \times 10^{-4}$ \\
\hline GO:0006468 & AB_up & protein phosphorylation & $3.99 \times 10^{-4}$ \\
\hline GO:0031640 & AB_up & killing of cells of other organism & $4.86 \times 10^{-4}$ \\
\hline GO:0009435 & $A B \_$up & NAD biosynthetic process & $1.02 \times 10^{-3}$ \\
\hline GO:0010200 & AB_up & response to chitin & $1.57 \times 10^{-3}$ \\
\hline GO:0006099 & $A B \_$_up & tricarboxylic acid cycle & $1.57 \times 10^{-3}$ \\
\hline GO:0016998 & AB_up & cell wall macromolecule catabolic process & $3.51 \times 10^{-3}$ \\
\hline GO:0006614 & AB_up & $\begin{array}{l}\text { SRP-dependent cotranslational protein targeting } \\
\text { to membrane }\end{array}$ & $3.51 \times 10^{-3}$ \\
\hline GO:0009694 & AB_up & jasmonic acid metabolic process & $3.76 \times 10^{-3}$ \\
\hline GO:0006096 & AB_up & glycolytic process & $4.47 \times 10^{-3}$ \\
\hline GO:0006457 & AB_up & protein folding & $6.42 \times 10^{-3}$ \\
\hline GO:0061025 & AB_up & membrane fusion & $6.54 \times 10^{-3}$ \\
\hline GO:0002181 & AB_up & cytoplasmic translation & $8.26 \times 10^{-3}$ \\
\hline
\end{tabular}


Table 2. Cont.

\begin{tabular}{cccc}
\hline GO and KEGG ID ${ }^{1}$ & Cluster $^{2}$ & Description $^{\text {cholse Discovery Rate }}{ }^{3}$ \\
\hline GO:0009423 & AB_up & chorismate biosynthetic process & $9.43 \times 10^{-3}$ \\
GO:0009873 & AB_up & ethylene-activated signaling pathway & $9.66 \times 10^{-3}$ \\
map00860 & AB_down & Porphyrin and chlorophyll metabolism & $4.23 \times 10^{-5}$ \\
map00670 & AB_down & One carbon pool by folate & $1.14 \times 10^{-3}$ \\
map00970 & AB_down & Aminoacyl-tRNA biosynthesis & $2.79 \times 10^{-3}$ \\
GO:0010088 & AB_down & phloem development & $5.04 \times 10^{-5}$ \\
GO:0009768 & AB_down & photosynthesis, light harvesting in photosystem I & $1.06 \times 10^{-4}$ \\
GO:0018298 & AB_down & protein-chromophore linkage & $1.22 \times 10^{-4}$ \\
GO:0006298 & AB_down & mismatch repair & $1.78 \times 10^{-3}$ \\
GO:0010206 & AB_down & photosystem II repair & $1.95 \times 10^{-3}$ \\
GO:0006418 & AB_down & tRNA aminoacylation for protein translation & $2.36 \times 10^{-3}$ \\
GO:0009234 & AB_down & menaquinone biosynthetic process & $3.43 \times 10^{-3}$ \\
GO:0045037 & AB_down & protein import into chloroplast stroma & $3.43 \times 10^{-3}$ \\
\hline
\end{tabular}

${ }^{1}$ IDs for Enriched Gene Ontology (GO) terms and Kyoto Encyclopedia of Gene and Genomes (KEGG) pathways were listed. GO (Biological Process only) was reduced to most specific terms. ${ }^{2}$ Hierarchical clusters of the DEGs and direction of gene expressions (up or down) are indicated. ${ }^{3}$ False discovery rate was used as correction for multiple tests [45]. For both KEGG and GO, adjusted $p$-value $<0.01$ are shown.

\subsection{Search for Tanoak Transcriptome Signatures Associated with Innate Resistance and Phosphite Treatment}

Our cluster analysis did not immediately identify innate resistance or phosphite induced transcriptome patterns, however, transcriptome patterns of T7 samples seemed to associate with the occurrence of $P$. ramorum transcripts. Among the eighteen inoculated T7 samples, seven tanoak leaf samples yielded cDNA sequence reads from $P$. ramorum which were above the baseline (Figure 5). The number of $P$. ramorum cDNA sequences mapped to the $P$. ramorum genome at $\mathrm{T} 7 \mathrm{did}$ not correlate with the observed disease responses, which were scored 35 days after inoculation (T35) and 28 days after T7 sample collection (Figure 5, Fisher's exact test $p=0.271$, Document S1). Although phosphite-untreated susceptible plants showed a high level of $P$. ramorum reads, the difference between phosphite-treated and untreated susceptible samples was not statistically significant (Mann Whitney U test $p=0.095$, Document S1). Detection of P. ramorum transcripts was however associated with hierarchical clusters. All seven samples with detectable levels of $P$. ramorum transcripts were found in either Cluster A or B (Fisher's exact test $p=0.004$ ), whereas samples with $P$. ramorum transcripts below threshold were found in all three clusters. In summary, global mRNA expression pattern of tanoak at T7 was most strongly associated with active growth of the pathogen inside the host tissue, but not with disease phenotypes at T35 $(p=0.271)$ or phosphite treatment $(p=0.370)$ (Figure $4 b$, Document S1).

The other aspect revealed by the hierarchical clustering analysis was that disease phenotypes at T35 did not always correlate with disease progression at T7. For instance, at T7, one out of seven susceptible plants showed global mRNA profiles associated with no infection (Library HS1A_index5 Figure 4b). On the other hand, four out of eleven resistant plants showed disease associated global mRNA profiles at T7 (cluster A or B in Figure 4b), and $P$. ramorum transcripts were detected in three of the four resistant samples. The observed inconsistency between transcriptomes and disease phenotypes indicated a large variation in disease progression among samples at T7, which can confound interpretation of transcriptome analysis. We therefore searched for the signature of innate resistance and phosphite-induced resistance only in the samples before inoculation (T0 samples) (Table 1). Due to small representation, Family 10 seedling samples were excluded from data analysis.

Untreated susceptible trees (Control susceptible: Cs) and untreated resistant trees (Control resistant: $\mathrm{Cr}$ ) before inoculation were compared in search of a transcriptome signature for innate resistance (Cs and $\mathrm{Cr}$ at $\mathrm{T} 0$ in Table 1, Table S4). The comparison using the English oak genome as a reference yielded 466 DEGs, of which 268 were upregulated in $\mathrm{Cr}$ plants. Interestingly, GSEA implicates enrichment of defense-related genes such as "Phenylpropanoid biosynthesis", "terpenoid biosynthetic process", "Biosynthesis of 
antibiotics", and "oxylipin biosynthetic process" are enriched in genes upregulated in resistant plants (Table 3).

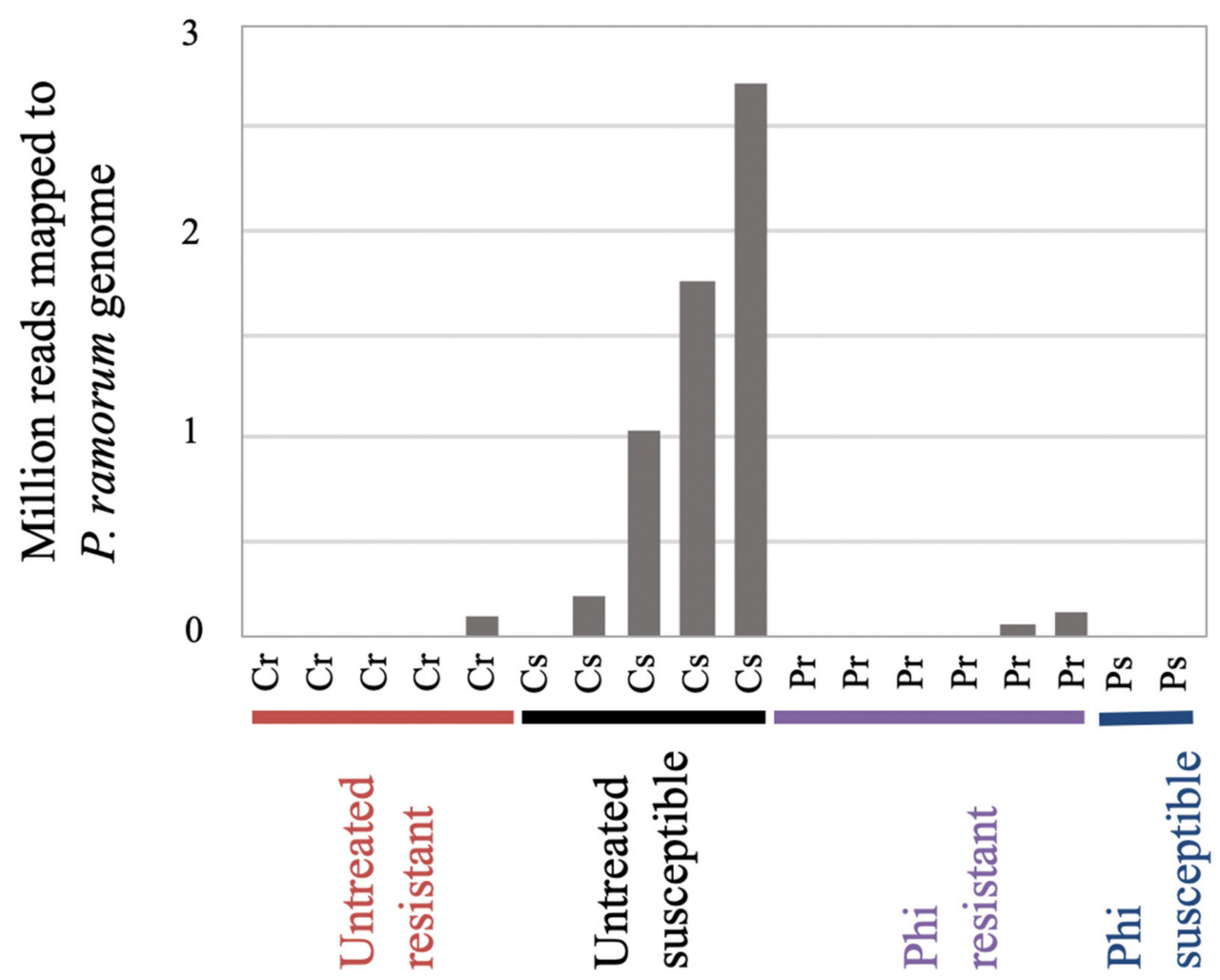

Figure 5. Number of reads from inoculated leaves at seven days post inoculation mapped to P. ramorum gene models [25] with Rsubread [34]. Samples are labeled as Untreated resistant (Cr), Untreated susceptible (Cs), Phosphite-treated resistant (Pr), Phosphite-treated susceptible (Ps).

Effects of phosphite on transcriptomes were examined through a comparison of phosphite treated (seven days post treatment) and phosphite untreated samples at T0 ( $\mathrm{P}$ and C plants at T0). No differentially expressed genes were detected (Table 1, Table S5).

Although its mode of action is not well understood, phosphites have been used to protect susceptible plants from pathogens. In order to highlight which genes may be involved in phosphite-induced resistance, susceptible untreated trees were compared to resistant phosphite-treated trees (Cs and Pr at T0 in Table 1, Table S6). Note that owing to difficulty in clonal propagation of tanoak, innate resistance of Pr plants were not evaluated. However, judging from the low frequency of innate resistance, most of Pr trees from Family 12 were unlikely to be innate-resistant to $P$. ramorum. Family 12 trees were the highest responders to the phosphite treatment: six out of eight untreated trees were susceptible, whereas all eight phosphite-treated trees were resistant to P. ramorum (Figure 2). Thirty-one genes were upregulated and 16 genes were downregulated in phosphite-treated resistant (Pr) trees (Table 1).

It was found that over half of DEGs (22 out of 31 DEGs) in the Cs Pr comparison are also DEGs in the Cs Cr comparison (Table 4). In other words, the changes in gene expression patterns observed in Cs plants following phosphite treatment (i.e., DEGs between Cs and $\mathrm{Pr}$ ) are positively correlated with the difference in gene expression between $\mathrm{Cs}$ and $\mathrm{Cr}$ plants. Enrichment of one GO term associated with phloem development as well as the triterpenoid biosynthetic process were found to be overrepresented among DEGs shared between $\mathrm{Cr}$ and $\mathrm{Pr}$ in comparison to Cs in Family 12 (Table 3) and two DEGs predicted as "SIEVE ELEMENT OCCLUSION B-like" were annotated with the GO term phloem development. Three genes involved in flavonoid modifications and four genes encoding 
LRR receptor-like serine threonine kinases (RLKs) were also upregulated in $\mathrm{Cr}$ as well as Pr plants (Table S6). These proteins have been implicated in active defense.

Table 3. GO enrichment analysis of deferentially expressed genes (DEGs) among innate resistant Family 12 plants.

\begin{tabular}{|c|c|c|c|}
\hline GO and KEGG ID ${ }^{1}$ & DEG Category $^{2}$ & Description & False Discovery Rate \\
\hline \multicolumn{4}{|l|}{ Crv. Cs } \\
\hline GO:0010951 & Cr_up & negative regulation of endopeptidase activity & $3.15 \times 10^{-9}$ \\
\hline GO:0055114 & Cr_up & oxidation-reduction process & $1.35 \times 10^{-6}$ \\
\hline GO:0042744 & Cr_up & hydrogen peroxide catabolic process & $3.19 \times 10^{-5}$ \\
\hline GO:0016114 & Cr_up & terpenoid biosynthetic process & $2.08 \times 10^{-4}$ \\
\hline GO:0098869 & Cr_up & cellular oxidant detoxification & $3.11 \times 10^{-4}$ \\
\hline GO:0006979 & Cr_up & response to oxidative stress & $3.64 \times 10^{-4}$ \\
\hline GO:0009423 & Cr_up & chorismate biosynthetic process & $1.17 \times 10^{-2}$ \\
\hline GO:0031408 & Cr_up & oxylipin biosynthetic process & $1.17 \times 10^{-2}$ \\
\hline GO:0046129 & Cr_up & purine ribonucleoside biosynthetic process & $1.73 \times 10^{-2}$ \\
\hline GO:0009072 & Cr_up & aromatic amino acid family metabolic process & $2.47 \times 10^{-2}$ \\
\hline GO:0006833 & Cr_up & water transport & $3.06 \times 10^{-2}$ \\
\hline GO:0008654 & Cr_up & phospholipid biosynthetic process & $3.34 \times 10^{-2}$ \\
\hline GO:0030245 & Cr_up & cellulose catabolic process & $4.40 \times 10^{-2}$ \\
\hline GO:0009742 & Cr_up & brassinosteroid mediated signaling pathway & $4.40 \times 10^{-2}$ \\
\hline GO:0046130 & Cr_up & purine ribonucleoside catabolic process & $4.45 \times 10^{-2}$ \\
\hline GO:0009693 & Cr_up & ethylene biosynthetic process & $4.45 \times 10^{-2}$ \\
\hline GO:0010087 & Cr_up & phloem or xylem histogenesis & $4.67 \times 10^{-2}$ \\
\hline map00940 & Cr_up & Phenylpropanoid biosynthesis & $8.47 \times 10^{-10}$ \\
\hline map01130 & Cr_up & Biosynthesis of antibiotics & $2.10 \times 10^{-6}$ \\
\hline map00270 & Cr_up & Cysteine and methionine metabolism & $6.46 \times 10^{-3}$ \\
\hline map00500 & Cr_up & Starch and sucrose metabolism & $4.97 \times 10^{-2}$ \\
\hline GO:0006417 & Cr_down & regulation of translation & $4.33 \times 10^{-2}$ \\
\hline GO:0006075 & Cr_down & (1->3)-beta-D-glucan biosynthetic process & $4.33 \times 10^{-2}$ \\
\hline GO:0009682 & Cr_down & induced systemic resistance & $4.33 \times 10^{-2}$ \\
\hline map00500 & Cr_down & Starch and sucrose metabolism & $1.13 \times 10^{-4}$ \\
\hline \multicolumn{4}{|l|}{$\begin{array}{c}\text { Crv. Cs \& Cs v. Pr } \\
\text { overlap }\end{array}$} \\
\hline GO:0010088 & Cr_up \& Pr_up & phloem development & $1.26 \times 10^{-2}$ \\
\hline GO:0016104 & Cr_up \& Pr_up & triterpenoid biosynthetic process & $4.50 \times 10^{-2}$ \\
\hline
\end{tabular}

${ }^{1}$ IDs for Enriched Gene Ontology (GO) terms and Kyoto Encyclopedia of Gene and Genomes (KEGG) pathways were listed. GO terms were reduced to most specific, and only GO terms in Biological Process category were shown; ${ }^{2}$ Upregulated or downregulated in $\mathrm{Cr}$ or $\mathrm{Cr}$ and Pr plants; Abbreviations: Cs water control susceptible, Cr water control resistant, Pr: phosphite-treated resistant.

Table 4. Deferentially expressed genes (DEGs) shared within tree family 12 in the comparisons of untreated susceptible trees (Cs) and phosphite-treated resistant trees (Ps) as well as untreated susceptible trees (Cs) and untreated resistant trees $(\mathrm{Cr})$ before inoculation.

\begin{tabular}{cccc}
\hline DEG Category $^{\mathbf{1}}$ & $\begin{array}{c}\text { Cs and Pr at T0 } \\
\text { (Phi-Induced Resistance) }\end{array}$ & $\begin{array}{c}\text { Cs and Cr at T0 } \\
\text { (Innate Resistance) }\end{array}$ & Overlap \\
\hline Cs_up & 16 & 198 & 3 \\
\hline Cs_down & 31 & 268 & 22 \\
\hline
\end{tabular}

${ }^{1}$ Differentially expressed genes are categorized to upregulated (Cs_up) and downregulated (Cs_down) in uninoculated susceptible trees.

\subsection{Analysis of in Planta Phytophthora Ramorum Transcriptomes}

Although the percentage of transcripts from the pathogen was low, Illumina RNA-Seq yielded between 96,647 to 2,713,332 reads for seven T7 samples. We tested for DEGs in in planta P. ramorum transcriptomes between phosphite-treated and untreated samples. Consequently, 20 DEGs, all upregulated in phosphite-treated samples, were identified (Table S7). GO enrichment analysis identified "pyridoxal phosphate $\left(\right.$ Vitamin $\left.\mathrm{B}_{6}\right)$ biosynthesis process" among phosphite upregulated genes (false discovery rate corrected $p=0.015$ ). Two genes 
for Vitamin $\mathrm{B}_{6}$ biosynthesis are known for involvement in detoxification. In addition, four ATP-binding cassette (ABC) transporters and one major facilitator superfamily (MFS) transporters, groups of genes often involved in drug resistance and detoxification [51], were identified. It is noteworthy that phosphite was applied to stems at the soil line, whereas transcriptomes were derived from inoculated leaves distant from the soil line. We did not quantify phosphite in the inoculated leaves, however, a strong influence of the systemic fungicide on the $P$. ramorum transcriptomes was revealed.

\section{Discussion}

Dual RNA-Seq in combination with hierarchical clustering and gene set enrichment analysis revealed a complicated interplay of $P$. ramorum, phosphite, and genetically heterogeneous tanoak individuals from a wild population. These analyses indicated a large variation in disease progression at $\mathrm{T} 7$ regardless of the genetic background of tanoak or phosphite treatment. In addition to the genetic makeup of host plants and phosphite treatment, age as well as developmental stage and history of microenvironmental conditions can inevitably influence the structural integrity of each leaf, and thus susceptibility to zoospores used as inocula. For instance, at T7, most resistant plants showed global mRNA profiles associated with healthy plants while others showed those associated with infection. This indicates that most resistant plants fended off the pathogen at the early stages of infection, perhaps as early as the time of pathogen entry, and thus either their transcriptomes had not been perturbed or they had come back to their basal state (Cluster C) at the time of sampling. In other cases, the pathogen may have initially invaded the plant tissue causing disease associated changes in expression (Cluster A or B), but the pathogen was then later cleared or contained, and failed to become established in resistant plants by T35. Transcriptomes of phosphite-treated samples at T7 were also diverse, and did not correlate well, regardless of their resistant or susceptible phenotype at T35. Hierarchical clustering analysis, as we demonstrated, is thus particularity useful to evaluate variation and reproducibility of disease-associated transcriptomes of non-clonal and/or developmentally heterogenous samples.

\subsection{Use of Organosilicate Surfactant for Phosphite Application}

Garbelotto et al. [28] reported that bark applications and soil drenches of unamended phosphites were not effective against Sudden Oak Death, while foliar applications of phosphites amended with a range of surfactants caused excessive phytotoxicity in oaks and tanoaks. Two treatment approaches instead were highly effective; injection of highly concentrated phosphites directly into the stem, a procedure that requires stems of at least $4 \mathrm{~cm}$ in diameter, and bark applications of phosphites with Pentra-Bark, a treatment that is feasible on smaller trees as well and thus was chosen as the only possible approach here, given the small size of the plants. Considering that phosphites are only effective when used with Pentra-Bark in this pathosystem, and based on the fact that this organosilicate surfactant is known to strongly adhere on the outer bark of the tree without any presumed effects on the pathogen or on tree physiology [21], we decided not to test the two compounds in separate treatments, given that bark applications of phosphites only or of Pentra-Bark only are not registered in California for the treatment of Sudden Oak Death in oaks and tanoaks. While an effect of Pentra-Bark on pathogen or host is unlikely, it is important to note that the effects measured and reported in this study were caused by the combined application of both compounds. When phosphite-treated (with Pentra-Bark) and phosphite-untreated samples were compared ( $\mathrm{C}$ and $\mathrm{P}$ plants at $\mathrm{T} 0$ in Table 1$)$, no deferentially expressed genes were detected. Noise in gene expression due to Pentra-Bark is thus likely low.

\subsection{Genes Involved in the Innate Resistance}

Due to a large variation in disease progression at T7, only T0 (pre-inoculation) samples were used to search for transcriptome signatures associated with innate resistance. Previous work indicates that disease resistance to Ramorum Blight in tanoak is quantitative 
(quantitative disease resistance, QDR) [20]. QDR is under the control of multiple and diverse classes of genes each with small effects [52,53]. QDR genes downstream to the event of MAMPs perception could be at a basal low expression state before inoculation, therefore they might not be detectable through the transcriptome comparison of uninoculated resistant and susceptible plants. Comparison of $\mathrm{Cr}$ and $\mathrm{Cs}$ plants at T0 (uninfected and phosphite-untreated) yielded 466 DEGs. Gene set enrichment analysis showed that before inoculation, defense related genes are upregulated in innate resistant plants $(\mathrm{Cr})$. For instance, terpenoids, chorismate, oxylipins, phenylpropanoids and antibiotics (Table 3) all directly or indirectly participate in production of defense metabolites [54-56]. Enrichment of GO term "negative regulation of endopeptidase activity" showed the smallest $p$-value $(p<0.001)$. Enrichment of this GO term has also been observed in a disease-tolerant rootstock of avocado plant in response to a fungal root pathogen Rosellinia necatrix in comparison to susceptible rootstocks [57] as well as in a disease-resistant spinach cultivar in response to an oomycete downy mildew pathogen Peronospora effusa in comparison to a susceptible cultivar [58].

\subsection{Phosphite-Induced Resistance}

As for the innate resistance, phosphite-induced resistance in tanoak is likely governed by quantitative trait loci (QTL). When phosphite treated samples and untreated samples at T0 (seven days post treatment) were compared, no DEGs was identified. In the $P$. infestans potato pathosystem, phosphite rapidly induced a transcriptome shift within $3 \mathrm{~h}$, the effect, however, lasted less than $24 \mathrm{~h} \mathrm{[59].} \mathrm{It} \mathrm{is} \mathrm{possible} \mathrm{that} \mathrm{phosphite-induced}$ transcriptome alteration and priming of systemic acquired resistance had taken place before our first sampling at seven days post-treatment. Hence, sampling at earlier time points, as early as three hours might have differentiated variations in phosphite-induced resistance. Comparison of Cs and Pr plants at T0 (seven days post treatment) identified 47 DEGsof these, 25 were shared with DEGs in the Cs and Cr plant comparison. Of the three phosphite-treated Family 12 trees, which showed the resistant phenotype (Table 1), the number of innate resistant plants is unknown due to unavailability of clonal propagation. If the frequency of innate resistant seedlings in Family 12 is $1 / 4$ as observed, it is highly unlikely that phosphite-treated plants showing resistance are due only to innate resistance $\left(p=(1 / 4)^{3}=0.015\right)$. Shared DEGs between (Cr v. Cs) and (Cs v. Pr) comparisons in Family 12 (Table 4) were likely due to the effect of phosphite on naturally susceptible plants.

Diverse classes of DEGs are shared between $\mathrm{Pr}$ and $\mathrm{Cr}$ plants. Upregulation of three genes for sieve element occlusion proteins and two genes for biosynthesis of triterpenoid beta-amyrin are attributable to the enrichment of GO terms "phloem development" and "triterpenoid biosynthetic process", respectively (Table 3). Homologs of sieve element occlusion proteins have shown to limit phloem mass flow in response to pathogen infection [60]. Beta-amyrin has been found in leaf epicuticular waxes of oak [61] and its derivatives show antifungal activity [62]. Furthermore, among DEGs shared between $\mathrm{Pr}$ and $\mathrm{Cr}$ plants, 4 out of 25 genes encode leucine rich repeat (LRR) proteins. Homologs of the LRR proteins include chitin [62] and flagellin [63] receptor proteins in Arabidopsis thaliana. Three genes for flavonoid-modifying enzymes were also shared between the two comparisons. Flavonoids are structurally diverse secondary metabolites in plants and one of their important functions is defense against pathogens and herbivores [64]. Importantly phosphite changed expression of the DEGs in the same direction as innate resistant plants in relation to susceptible plants, which coincided with the acquisition of resistance to Phytophthora infection. This transcriptional response is in line with the proposed mechanism in which phosphite stimulates extant host defenses and increases the resistance of susceptible host plants to infection by Phytophthora $[7,10,11]$.

\subsection{Use of English Oak as a Reference for Tanoak RNA-Seq Analysis}

Due to the unavailability of the genome sequence of tanoak, the English oak genome was used as a reference to analyze the tanoak transcriptome. Over $90 \%$ of tanoak sequenc- 
ing reads were mapped to the English oak genome (Table S1) and were subsequently used for data analysis. It should be noted that tanoak specific genes and genes diverged from homologs in English oak are not represented in this work. A genome sequence project of tanoak is currently underway, and use of the tanoak genome will inevitably improve the outcome of data analysis. Nevertheless, our present work provides a general picture of tanoak transcriptomes associated with innate resistance, phosphite-induced resistance, and phytophthora infection. It would be interesting to evaluate the conservation of gene regulations in phosphite-induced resistance in closely related host species such as oaks, chestnuts, and walnuts.

\subsection{Phosphite-Induced Transcriptome Changes of P. ramorum}

Several lines of evidence suggest that at high concentrations, phosphite directly inhibits the growth of Phytophthora species through direct toxicity [65]. The effect of phosphite on the transcriptome of $P$. cinnamomi grown on a culture medium has been investigated [66]. At $40 \mu \mathrm{g} / \mathrm{mL}$ of phosphite, P. cinnamomi showed a severe growth inhibition and lysis of the hyphal wall, while 32 genes were reported to be differentially expressed. There are several features shared with our in planta data set. For instance, multiple $\mathrm{ABC}$ transporters were detected in upregulated as well as downregulated gene sets of P. cinnamomi in response to phosphite. Likewise, several ABC transporters were also differentially expressed in P. ramorum in phosphite-treated plants. Homologs of two of the $P$. ramorum $\mathrm{ABC}$ transporters upregulated in phosphite-treated tanoak seedlings are found in plant pathogenic fungi Magnaporthe oryzae (Abc3 gene) [67] and Fusarium sambucinum (Gpabc1 gene) [68], and these fungal homologs participate in efflux of toxins. A vitamin $\mathrm{B}_{6}$ biosynthesis gene was detected in P. cinnamomi, which is consistent with our GO enrichment analysis where "pyridoxal phosphate biosynthetic process" (synonym: "active vitamin $B_{6}$ biosynthesis") was detected in the upregulated set in phosphite treated samples. In fungal plant pathogens, vitamin $B_{6}[69]$ as well as glutathione S-transferase [70] (also upregulated in P. ramorum in phosphite-treated plant tissue) function as antioxidant stress protectors against reactive oxygen species. The observed upregulation of genes for antioxidant production in this research is consistent with the P. palmivora and A. thaliana pathosystem, in which phosphite-treated plants rapidly released superoxide [11]. Among the seven in planta transcriptomes of P. ramorum, two were from phosphite-treated resistant (Pr) plants. Neither of the two phosphite-treated T7 susceptible plant samples (Ps) yielded $P$. ramorum transcripts. In other words, both transcriptomes of $P$. ramorum from phosphitetreated plants represent those eventually contained by host defense systems. Lysis of hyphal wall and release of MAMPs will evidently further activate the host defense [1,4]. The direction of future work will be to understand phosphite-induced resistance at a high spatio-temporal resolution. This can be achieved by comparing $P$. ramorum invasion and progression in Cs and Pr plants through RNA-Seq while controlling developmental stages of the pathogen in planta by monitoring a fluorescent protein (GFP)-tagged strain of $P$. ramorum in the tanoak tissue.

\section{Conclusions}

Transcriptome analysis identified candidate genes involved in natural resistance to Sudden Oak Death, as well as genes possibly associated with phosphite-induced resistance. Sets of candidate genes for innate resistance and phosphite-induced resistance largely overlapped, and a large part of the overlapped genes implicated plant defense processes. Thus, our transcriptome analysis is in line with the hypothesis that phosphite increases the resistance of susceptible host species to Phytophthora infection. When transcriptomes of $P$. ramorum were compared in phosphite-treated and untreated plants, genes for membrane transporters and vitamin $\mathrm{B}_{6}$ biosynthesis were found active, which is consistent with direct toxicity of phosphite on the pathogen. We have shown the importance and power of dual RNA-Seq in plant-pathogen interactions as well as plant-pathogen-pesticide interactions. Perturbation of transcriptome due to interactions and enrichment of pathways or gene 
functions helped discern physiological changes of the host and pathogen. Differentially expressed genes associated with innate resistance and/or phosphite-induced resistance can be used to develop mRNA markers for screening and marker-assisted breeding of tanoak.

Supplementary Materials: The following are available online at https:/ /www.mdpi.com/2309-608 X/7/3/198/s1. Document S1. Details of Fisher's exact test and Wilcox test presented in this paper. Table S1. RNA quality of tanoak samples, Table S2. Quercus robur gene annotation, Table S3. DEGs of tanoak between hierarchical clusters AB and C, Table S4. DEGs between Cr and Cs plants at T0, Table S5. DEGs between C and P plants at T0, Table S6. DEGs between Cs and Pr plants at T0, Table S7. DEGs between P. ramorum in phosphite-treated and un-treated tanoak seedlings.

Author Contributions: Project was conceived and planned by K.J.H., J.W.W., and M.G.; inoculation studies were performed by K.J.H. and C.A.E.; RNA extraction and sequencing library preparation were performed by S.S., K.J.H., and C.A.E.; bioinformatics were performed by S.S., P.J.P.C., and T.K.; manuscript preparation by K.J.H., C.A.E., P.J.P.C. and T.K., with discussion from J.W.W. and M.G. All authors have read and agreed to the published version of the manuscript.

Funding: This work was supported by the Gordon and Betty Moore Foundation Grant \#2639 to MG; the United States Department of Agriculture-Agriculture Research Service, CRIS Project \# 5306-22000-014-00D to TK.

Institutional Review Board Statement: Not applicable.

Informed Consent Statement: Not applicable.

Data Availability Statement: Not applicable.

Acknowledgments: The authors would like to acknowledge Point Reyes National Seashore for tanoak seeds; Marissa J Montjoy for technical assistance, Melina Kozanitas for providing the isolate MK1461 and associated information; Brian Knaus and Lutz Froenicke for helpful comments on data analyses. Any use of trade, product or firm names is for descriptive purposes only and does not imply endorsement by the U.S. Government.

Conflicts of Interest: The authors declare no conflict of interest.

\section{References}

1. Guest, D.; Grant, B. The Complex Action of Phosphonates as Antifungal Agents. Biol. Rev. 1991, 66, 159-187. [CrossRef]

2. Hardy, G.E.S.J.; Barrett, S.; Shearer, B.L. The Future of Phosphite as a Fungicide to Control the Soilborne Plant Pathogen Phytophthora Cinnamomi in Natural Ecosystems. Australas. Plant Pathol. 2001, 30, 133-139. [CrossRef]

3. Solla, A.; Moreno, G.; Malewski, T.; Jung, T.; Klisz, M.; Tkaczyk, M.; Siebyla, M.; Pérez, A.; Cubera, E.; Hrynyk, H.; et al. Phosphite Spray for the Control of Oak Decline Induced by Phytophthora in Europe. For. Ecol. Manag. 2021, 485, 118938. [CrossRef]

4. Dalio, R.J.D.; Fleischmann, F.; Humez, M.; Osswald, W. Phosphite Protects Fagus Sylvatica Seedlings towards Phytophthora Plurivora via Local Toxicity, Priming and Facilitation of Pathogen Recognition. PLoS ONE 2014, 9, e87860. [CrossRef]

5. Smillie, R.; Grant, B.; Guest, D. The Mode of Action of Phosphite: Evidence for Both Direct and Indirect Modes of Action on 3 Phytophthora Spp in Plants. Phytopathology 1989, 79, 921-926. [CrossRef]

6. Wilkinson, C.J.; Holmes, J.M.; Dell, B.; Tynan, K.M.; McComb, J.A.; Shearer, B.L.; Colquhoun, I.J.; Hardy, G.E.S. Effect of Phosphite on in Planta Zoospore Production of Phytophthora Cinnamomi. Plant Pathol. 2001, 50, 587-593. [CrossRef]

7. Grant, B.; Dunstan, R.; Griffith, J.; Niere, J.; Smillie, R. The Mechanism of Phosphonic (Phosphorous) Acid Action in Phytophthora. Australas. Plant Pathol. 1990, 19, 115. [CrossRef]

8. Jackson, T.J.; Burgess, T.; Colquhoun, I.; Hardy, G. Action of the Fungicide Phosphite on Eucalyptus Marginata Inoculated with Phytophthora Cinnamomi. Plant Pathol. 2000, 49, 147-154. [CrossRef]

9. Massoud, K.; Barchietto, T.; Rudulier, T.L.; Pallandre, L.; Didierlaurent, L.; Garmier, M.; Ambard-Bretteville, F.; Seng, J.-M.; Saindrenan, P. Dissecting Phosphite-Induced Priming in Arabidopsis Infected with Hyaloperonospora Arabidopsidis. Plant Physiol. 2012, 159, 286-298. [CrossRef]

10. Guest, D.; Bompeix, G. The Complex Mode of Action of Phosphonates. Australas. Plant Pathol. 1990, 19, 113. [CrossRef]

11. Daniel, R.; Guest, D. Defence Responses Induced by Potassium Phosphonate in Phytophthora Palmivora-Challenged Arabidopsis Thaliana. Physiol. Mol. Plant Pathol. 2005, 67, 194-201. [CrossRef]

12. Rizzo, D.M.; Garbelotto, M. Sudden Oak Death: Endangering California and Oregon Forest Ecosystems. Front. Ecol. Environ. 2003, 1, 197-204. [CrossRef]

13. Rizzo, D.M.; Garbelotto, M.; Hansen, E.A. Phytophthora Ramorum: Integrative Research and Management of an Emerging Pathogen in California and Oregon Forests. Annu. Rev. Phytopathol. 2005, 43, 309-335. [CrossRef] 
14. Parke, J.L.; Peterson, E.K. Sudden Oak Death, Sudden Larch Death, and Ramorum Blight. Available online: https://www.apsnet. org/edcenter/disandpath/oomycete/pdlessons/Pages/SuddenOakDeath.aspx (accessed on 8 March 2021).

15. Maloney, P.; Lynch, S.; Kane, S.; Jensen, C.; Rizzo, D. Establishment of an Emerging Generalist Pathogen in Redwood Forest Communities. J. Ecol. 2005, 93, 899-905. [CrossRef]

16. McPherson, B.; Mori, S.; Wood, D.; Storer, A.; Svihra, P.; Kelly, N.; Standiford, R. Sudden Oak Death in California: Disease Progression in Oaks and Tanoaks. For. Ecol. Manag. 2005, 213, 71-89. [CrossRef]

17. Meentemeyer, R.; Rank, N.; Shoemaker, D.; Oneal, C.; Wickland, A.; Frangioso, K.; Rizzo, D. Impact of Sudden Oak Death on Tree Mortality in the Big Sur Ecoregion of California. Biol. Invasions 2008, 10, 1243-1255. [CrossRef]

18. Dillon, W.W.; Meentemeyer, R.K.; Vogler, J.B.; Cobb, R.C.; Metz, M.R.; Rizzo, D.M. Range-Wide Threats to a Foundation Tree Species from Disturbance Interactions. Madroño 2013, 60, 139-150. [CrossRef]

19. Filipe, J.A.N.; Cobb, R.C.; Salmon, M.; Gilligan, C.A. Management Strategies for Conservation of Tanoak in California Forests Threatened by Sudden Oak Death: A Disease-Community Feedback Modelling Approach. Forests 2019, 10, 1103. [CrossRef]

20. Hayden, K.J.; Garbelotto, M.; Dodd, R.; Wright, J.W. Scaling up from Greenhouse Resistance to Fitness in the Field for a Host of an Emerging Forest Disease. Evol. Appl. 2013, 6, 970-982. [CrossRef] [PubMed]

21. Garbelotto, M.; Schmidt, D.J. Phosphonate Controls Sudden Oak Death Pathogen for up to 2 Years. Calif. Agric. 2009, 63, 10-17. [CrossRef]

22. Bowcutt, F. The Tanoak Tree: An Environmental History of a Pacific Coast Hardwood; University of Washington Press: Seattle, 2015; ISBN 978-0-295-99464-2.

23. Nettel, A.; Dodd, R.; Afzal-Rafii, Z. Genetic Diversity, Structure, and Demographic Change in Tanoak, Lithocarpus Densiflorus (Fagaceae), the Most Susceptible Species to Sudden Oak Death in California. Am. J. Bot. 2009, 96, 2224-2233. [CrossRef] [PubMed]

24. Roy, B.; Kirchner, J. Evolutionary Dynamics of Pathogen Resistance and Tolerance. Evolution 2000, 54, 51-63. [CrossRef] [PubMed]

25. Tyler, B.; Tripathy, S.; Zhang, X.; Dehal, P.; Jiang, R.; Aerts, A.; Arredondo, F.; Baxter, L.; Bensasson, D.; Beynon, J.; et al. Phytophthora Genome Sequences Uncover Evolutionary Origins and Mechanisms of Pathogenesis. Science 2006, 313, 1261-1266. [CrossRef]

26. Hayden, K.J.; Garbelotto, M.; Knaus, B.J.; Cronn, R.C.; Rai, H.; Wright, J.W. Dual RNA-Seq of the Plant Pathogen Phytophthora Ramorum and Its Tanoak Host. Tree Genet. Genomes 2014, 10, 489-502. [CrossRef]

27. Baker, K.F. The U. C. System for Producing Healthy Container-Grown Plants through the Use of Clean Soil, Clean Stock, and Sanitation; University of California, Division of Agricultural Sciences, Agricultural Experiment Station, Extension Service: Berkeley, CA, USA, 1957.

28. Garbelotto, M.; Schmidt, D.J.; Harnik, T.Y. Phosphite Injections and Bark Application of Phosphite + PentrabarkTM Control Sudden Oak Death in Coast Live Oak. Arboricult. Urban For. 2007, 309-317.

29. Erwin, D.C.; Ribeiro, O.K. Phytophthora Diseases Worldwide; APS Press: St. Paul, MN, USA, 1996; ISBN 0-89054-212-0.

30. Chang, S.; Puryear, J.; Cairney, J. A Simple and Efficient Method for Isolating RNA from Pine Trees. Plant Mol. Biol. Rep. 2007, 11, 113-116. [CrossRef]

31. Le Provost, G.; Herrera, R.; Paiva, J.; Chaumeil, P.; Salin, F.; Plomion, C. A Micromethod for High Throughput RNA Extraction in Forest Trees. Biol. Res. 2007, 40, 291-297. [CrossRef]

32. Kim, W.-S.; Haj-Ahmod, Y. Evaluation of Plant RNA Integrity Number (RIN) Generated Using an Agilent BioAnalyzer 2100 Available online: https://norgenbiotek.com/sites/default/files/resources/plant_microrna_purification_kit_evaluation_of_ plant_rna_integrity_number_rin_generated_using_an_agilent_bioanalyzer_2100_application_notes_599.pdf (accessed on 14 January 2020).

33. Wang, L.; Nie, J.; Sicotte, H.; Li, Y.; Eckel-Passow, J.E.; Dasari, S.; Vedell, P.T.; Barman, P.; Wang, L.; Weinshiboum, R.; et al. Measure Transcript Integrity Using RNA-Seq Data. BMC Bioinform. 2016, 17, 58. [CrossRef]

34. Liao, Y.; Smyth, G.K.; Shi, W. The R Package Rsubread Is Easier, Faster, Cheaper and Better for Alignment and Quantification of RNA Sequencing Reads. Nucleic Acids Res. 2019, 47, e47. [CrossRef]

35. R Core Team R: A Language and Environment for Statistical Computing. R Foundation for Statistical Computing, Vienna, Austria. Available online: https:/ / www.r-project.org/ (accessed on 9 March 2021).

36. Li, H.; Handsaker, B.; Wysoker, A.; Fennell, T.; Ruan, J.; Homer, N.; Marth, G.; Abecasis, G.; Durbin, R. The Sequence Alignment/Map Format and SAMtools. Bioinformatics 2009, 25, 2078-2079. [CrossRef] [PubMed]

37. Ashburner, M.; Ball, C.A.; Blake, J.A.; Botstein, D.; Butler, H.; Cherry, J.M.; Davis, A.P.; Dolinski, K.; Dwight, S.S.; Eppig, J.T.; et al. Gene Ontology: Tool for the Unification of Biology. The Gene Ontology Consortium. Nat. Genet. 2000, 25, 25-29. [CrossRef]

38. The Gene Ontology Consortium Expansion of the Gene Ontology Knowledgebase and Resources. Nucleic Acids Res. 2017, 45, D331-D338. [CrossRef] [PubMed]

39. Kanehisa, M.; Goto, S. KEGG: Kyoto Encyclopedia of Genes and Genomes. Nucleic Acids Res. 2000, 28, 27-30. [CrossRef]

40. Conesa, A.; Götz, S.; García-Gómez, J.M.; Terol, J.; Talón, M.; Robles, M. Blast2GO: A Universal Tool for Annotation, Visualization and Analysis in Functional Genomics Research. Bioinformatics 2005, 21, 3674-3676. [CrossRef]

41. Plomion, C.; Aury, J.-M.; Amselem, J.; Leroy, T.; Murat, F.; Duplessis, S.; Faye, S.; Francillonne, N.; Labadie, K.; Provost, G.L.; et al. Oak Genome Reveals Facets of Long Lifespan. Nat. Plants 2018, 4, 440. [CrossRef]

42. Eisen, M.B.; Spellman, P.T.; Brown, P.O.; Botstein, D. Cluster Analysis and Display of Genome-Wide Expression Patterns. Proc. Natl. Acad. Sci. USA 1998, 95, 14863-14868. [CrossRef] 
43. Love, M.I.; Huber, W.; Anders, S. Moderated Estimation of Fold Change and Dispersion for RNA-Seq Data with DESeq2. Genome Biol. 2014, 15. [CrossRef]

44. Subramanian, A.; Tamayo, P.; Mootha, V.K.; Mukherjee, S.; Ebert, B.L.; Gillette, M.A.; Paulovich, A.; Pomeroy, S.L.; Golub, T.R.; Lander, E.S.; et al. Gene Set Enrichment Analysis: A Knowledge-Based Approach for Interpreting Genome-Wide Expression Profiles. Proc. Natl. Acad. Sci. USA 2005, 102, 15545-15550. [CrossRef]

45. Benjamini, Y.; Hochberg, Y. Controlling the False Discovery Rate: A Practical and Powerful Approach to Multiple Testing. J. R. Stat. Soc. Ser. B (Methodol.) 1995, 57, 289-300. [CrossRef]

46. Garbelotto, M.; Harnik, T.Y.; Schmidt, D.J. Efficacy of Phosphonic Acid, Metalaxyl-M and Copper Hydroxide against Phytophthora Ramorum in Vitro and in Planta. Plant Pathol. 2009, 58, 111-119. [CrossRef]

47. Dixon, R.; Paiva, N. Stress-Induced Phenylpropanoid Metabolism. Plant Cell 1995, 7, 1085-1097. [CrossRef] [PubMed]

48. Bilgin, D.D.; Zavala, J.A.; Zhu, J.; Clough, S.J.; Ort, D.R.; DeLucia, E.H. Biotic Stress Globally Downregulates Photosynthesis Genes. Plant Cell Environ. 2010, 33, 1597-1613. [CrossRef] [PubMed]

49. Jiang, Z.; Dong, X.; Zhang, Z. Network-Based Comparative Analysis of Arabidopsis Immune Responses to Golovinomyces Orontii and Botrytis Cinerea Infections. Sci. Rep. 2016, 6, 19149. [CrossRef] [PubMed]

50. Jiang, Z.; He, F.; Zhang, Z. Large-Scale Transcriptome Analysis Reveals Arabidopsis Metabolic Pathways Are Frequently Influenced by Different Pathogens. Plant Mol. Biol. 2017, 94, 453-467. [CrossRef] [PubMed]

51. Fisher, M.C.; Hawkins, N.J.; Sanglard, D.; Gurr, S.J. Worldwide Emergence of Resistance to Antifungal Drugs Challenges Human Health and Food Security. Science 2018, 360, 739-742. [CrossRef] [PubMed]

52. French, E.; Kim, B.-S.; Iyer-Pascuzzi, A.S. Mechanisms of Quantitative Disease Resistance in Plants. Semin. Cell Dev. Biol. 2016, 56, 201-208.

53. Poland, J.A.; Balint-Kurti, P.J.; Wisser, R.J.; Pratt, R.C.; Nelson, R.J. Shades of Gray: The World of Quantitative Disease Resistance Trends Plant Sci. 2009, 14, 21-29. [CrossRef]

54. Dixon, R.A.; Achnine, L.; Kota, P.; Liu, C.-J.; Reddy, M.S.S.; Wang, L. The Phenylpropanoid Pathway and Plant Defence-a Genomics Perspective. Mol. Plant Pathol. 2002, 3, 371-390. [CrossRef]

55. Ruan, J.; Zhou, Y.; Zhou, M.; Yan, J.; Khurshid, M.; Weng, W.; Cheng, J.; Zhang, K. Jasmonic Acid Signaling Pathway in Plants. Int. J. Mol. Sci. 2019, 20. [CrossRef]

56. Cheng, A.-X.; Lou, Y.-G.; Mao, Y.-B.; Lu, S.; Wang, L.-J.; Chen, X.-Y. Plant Terpenoids: Biosynthesis and Ecological Functions. J. Integr. Plant Biol. 2007, 49, 179-186. [CrossRef]

57. Zumaquero, A.; Martínez-Ferri, E.; Matas, A.J.; Reeksting, B.; Olivier, N.A.; Pliego-Alfaro, F.; Barceló, A.; van den Berg, N.; Pliego, C. Rosellinia Necatrix Infection Induces Differential Gene Expression between Tolerant and Susceptible Avocado Rootstocks. PLoS ONE 2019, 14. [CrossRef]

58. Kandel, S.L.; Hulse-Kemp, A.M.; Stoffel, K.; Koike, S.T.; Shi, A.; Mou, B.; Van Deynze, A.; Klosterman, S.J. Transcriptional Analyses of Differential Cultivars during Resistant and Susceptible Interactions with Peronospora Effusa, the Causal Agent of Spinach Downy Mildew. Sci. Rep. 2020, 10, 6719. [CrossRef]

59. Burra, D.D.; Berkowitz, O.; Hedley, P.E.; Morris, J.; Resjö, S.; Levander, F.; Liljeroth, E.; Andreasson, E.; Alexandersson, E. Phosphite-Induced Changes of the Transcriptome and Secretome in Solanum Tuberosum Leading to Resistance against Phytophthora Infestans. BMC Plant Biol. 2014, 14, 254. [CrossRef]

60. Pagliari, L.; Buoso, S.; Santi, S.; Furch, A.C.; Martini, M.; Degola, F.; Loschi, A.; Bel, V.; Je, A.; Musetti, R. Filamentous Sieve Element Proteins Are Able to Limit Phloem Mass Flow, but Not Phytoplasma Spread. J. Exp. Bot. 2017, 68, 3673-3688. [CrossRef] [PubMed]

61. Prasad, R.B.N.; Moller, E.; Gülz, P.-G. Epicuticular Waxes from Leaves of Quercus Robur. Phytochemistry 1990, 29, 2101-2103. [CrossRef]

62. Johann, S.; Soldi, C.; Lyon, J.P.; Pizzolatti, M.G.; Resende, M.A. Antifungal Activity of the Amyrin Derivatives and in Vitro Inhibition of Candida Albicans Adhesion to Human Epithelial Cells. Lett. Appl. Microbiol. 2007, 45, 148-153. [CrossRef] [PubMed]

63. Gómez-Gómez, L.; Boller, T. FLS2: An LRR Receptor-like Kinase Involved in the Perception of the Bacterial Elicitor Flagellin in Arabidopsis. Mol. Cell 2000, 5, 1003-1011. [CrossRef]

64. Mathesius, U. Flavonoid Functions in Plants and Their Interactions with Other Organisms. Plants 2018, 7. [CrossRef]

65. Fenn, M.; Coffey, M. Studies on the in Vitro and in Vivo Antifungal Activity of Fosetyl-Al and Phosphorus Acid. Phytopathology 1984, 74, 606-611. [CrossRef]

66. King, M.; Reeve, W.; Van der Hoek, M.B.; Williams, N.; McComb, J.; O’Brien, P.A.; Hardy, G.E.S.J. Defining the PhosphiteRegulated Transcriptome of the Plant Pathogen Phytophthora Cinnamomi. Mol. Genet. Genomics 2010, 284, 425-435. [CrossRef] [PubMed]

67. Patkar, R.N.; Xue, Y.K.; Shui, G.; Wenk, M.R.; Naqvi, N.I. Abc3-Mediated Efflux of an Endogenous Digoxin-like Steroidal Glycoside by Magnaporthe Oryzae Is Necessary for Host Invasion during Blast Disease. PLoS Pathog. 2012, 8, e1002888. [CrossRef]

68. Fleißner, A.; Sopalla, C.; Weltring, K.-M. An ATP-Binding Cassette Multidrug-Resistance Transporter Is Necessary for Tolerance of Gibberella Pulicaris to Phytoalexins and Virulence on Potato Tubers. Mol. Plant Microbe Interact. 2002, 15, 102-108. [CrossRef] [PubMed] 
69. Bilski, P.; Li, M.Y.; Ehrenshaft, M.; Daub, M.E.; Chignell, C.F. Vitamin B6 (Pyridoxine) and Its Derivatives Are Efficient Singlet Oxygen Quenchers and Potential Fungal Antioxidants. Photochem. Photobiol. 2000, 71, 129-134. [CrossRef]

70. Samsatly, J.; Copley, T.R.; Jabaji, S.H. Antioxidant Genes of Plants and Fungal Pathogens Are Distinctly Regulated during Disease Development in Different Rhizoctonia Solani Pathosystems. PLoS ONE 2018, 13. [CrossRef] [PubMed] 